Vol.45, n. 4 : pp. 519-524, December 2002 ISSN 1516-8913 Printed in Brazil

\title{
Essential Oils of Mentha pulegium and Mentha rotundifolia from Uruguay
}

\author{
Daniel Lorenzo ${ }^{1}$, Daniel Paz ${ }^{1}$ Eduardo Dellacassa ${ }^{1 *}$, Philip Davies ${ }^{2}$, Roser Vila ${ }^{3}$ and \\ Salvador Cañigueral ${ }^{3}$ \\ ${ }^{I}$ Cátedra de Farmacognosia y Productos Naturales; Facultad de Química; Universidad de la República; \\ Av. General Flores 2124; C. P. 11800; Tel. 005982 9244068; Fax 005982 9241906; edellac@bilbo.edu.uy; \\ Montevideo - Uruguay. ${ }^{2}$ Centro de Orientación Técnica y Económica de las Producciones Aromáticas (COTEPA); \\ Estación Experimental INIA Las Brujas; Ruta 48; Km 10; Rincón del Colorado - Canelones - Uruguay. ${ }^{3}$ Unitat de \\ Farmacologia i Farmacognòsia; Facultat de Farmàcia; Universitat de Barcelona; Av. Diagonal, 643; E-08028; \\ Barcelona - Spain
}

\begin{abstract}
Essential oils obtained by hydrodistillation from leaves of Mentha pulegium L. and Mentha rotundifolia (L.) Huds. from Uruguay were analysed by GC-FID and GC-MS. Oxygen-containing monoterpenes were the main group of constituents in both oils. Pulegone, isomenthone and menthone were the major components in the oil of M. pulegium, whereas piperitenone oxide and (Z)-sabinene hydrate were the major ones in $\mathrm{M}$. rotundifolia. Enantiomerically pure (-)-menthone, (+)-isomenthone, (+)-isomenthol, (-)-menthol and (+)-pulegone were detected by multidimensional gas chromatography in the case of M. pulegium oil.
\end{abstract}

Key Words: Mentha essential oil; multidimensional chiral gas chromatography

\section{INTRODUCTION}

The genus Mentha (Lamiaceae) includes aromatic herbs of difficult taxonomic classification due to a great variability in their morphological characters and frequent hybridisation. Previous investigations of their essential oils have revealed the existence of an important chemical polymorphism (Lawrence, 1978) and several varieties and chemotypes have been described for M. spicata (Kokkini and Vokou, 1989; Misra et al., 1989; Pino et al., 1998), Mentha longifolia (Maffei, 1988; Venskutonis, 1996), M. suaveolens (Hendriks and Van Os, 1976) and M. diemenica (Brophy et al., 1996) among others. M. pulegium L., commonly known as pennyroyal, is traditionally used in the treatment of flatulent dyspepsia and intestinal colic due to its carminative and antispasmodic properties (Newall et al., 1996). Previous reports (Lawrence, 1998; Hefendehl, 1970; Pino et al., 1996) on the composition of its essential oil showed that pulegone was the main constituent, and its percentage ranged from 25 to $92 \%$.

$M$. rotundifolia (L.) Huds. is an hybrid between $M$. longifolia (L.) L. and M. suaveolens Ehrh., whose essential oil has been the object of several studies (Nagell and Hefendehl, 1974; Kokkini and Papageorgiou, 1988; Hendriks et al., 1976; Umemoto, 1998), and different chemotypes have been characterised. Some authors have considered

\footnotetext{
*Author for correspondence
} 
M. rotundifolia (L.) Huds. as a synonym of $M$. suaveolens Ehrh (Hendriks and Van Os, 1976).

The present paper deals on the chemical composition of the essential oils of M. pulegium and $M$. rotundifolia grown wildly in Uruguay as well as on the enantiomeric distribution of the major chiral constituents of its oil.

\section{MATERIAL AND METHODS}

Plant Material and Isolation of Volatile Constituents: Flowering aerial parts of $M$. pulegium and M. rotundifolia were collected from the North of Montevideo (Uruguay) during the end of January 1997. Voucher specimens were included in the Herbarium of the Faculty of Agronomy of the University of the Republic (Montevideo, Uruguay) with the numbers MVFA 26337 and MVFA 26356, respectively.

Air-dried plant material was submitted to hydrodistillation in a Clevenger-type apparatus, affording essential oil yields of 1.93 and $1.02 \%$ $(\mathrm{v} / \mathrm{w})$, respectively.

GC Analysis: The analysis of the oil was carried out by GC on a Shimadzu 14 B gas chromatograph equipped with a FID and a Shimadzu data processor software EZ-Chrom, using two capillary columns. The first was a SE-52 (Mega, Legnano, Italy) cross-linked fused-silica capillary column coated with $5 \%$ phenyl-polymethylsiloxane $(30 \mathrm{~m}$ x $0.32 \mathrm{~mm}$ i.d. $\mathrm{x} 0.40-0.45 \mu \mathrm{m}$ film thickness); column temperature, $60^{\circ} \mathrm{C}(8 \mathrm{~min})$ to $180^{\circ} \mathrm{C}$ at $3^{\circ} \mathrm{C} / \mathrm{min}, 180-250^{\circ} \mathrm{C}$ at $20^{\circ} \mathrm{C} / \mathrm{min}, 250^{\circ} \mathrm{C}(10 \mathrm{~min})$. Injector temperature $250^{\circ} \mathrm{C}$; detector temperature $280^{\circ} \mathrm{C}$; injection mode, split; split ratio 1:30; volume injected, $0.2 \mu \mathrm{L}$ of the oil. Carrier gas was Hydrogen, $55 \mathrm{kPa}$. The second was a Carbowax 20M (Ohio Valley, USA) bonded fused-silica capillary column coated with polyethylene glycol ( $25 \mathrm{~m} \mathrm{x} 0.32 \mathrm{~mm}$ i.d. $\times 0.25 \mu \mathrm{m}$ film thickness); column temperature, $40^{\circ} \mathrm{C}(8 \mathrm{~min})$ to $180^{\circ} \mathrm{C}$ at $3^{\circ} \mathrm{C} / \mathrm{min}$, to $230^{\circ} \mathrm{C}$ at $20^{\circ} \mathrm{C} / \mathrm{min}$. Injector temperature $250^{\circ} \mathrm{C}$; detector temperature $250^{\circ} \mathrm{C}$; injection mode, split; split ratio 1:30; volume injected, $0.2 \mu \mathrm{L}$ of the oil. Carrier gas was Hydrogen, $30 \mathrm{kPa}$.

GC/MS Analysis: GC/MS analysis was conducted using a Shimadzu QP 5050 equipped with reference libraries (Adams, 1995; McLafferty and
Stauffer, 1991) using two capillary columns. The first was a SE-52 (Mega, Legnano, Italy) crosslinked fused-silica capillary column coated with $5 \%$ phenyl-polymethylsiloxane $(25 \mathrm{~m} \mathrm{x} 0.25 \mathrm{~mm}$ i.d. $\mathrm{x} \quad 0.25 \mu \mathrm{m}$ film thickness); column temperature, $60^{\circ} \mathrm{C}(8 \mathrm{~min})$ to $180^{\circ} \mathrm{C}$ at $3^{\circ} \mathrm{C} / \mathrm{min}$, to $230^{\circ} \mathrm{C}$ at $20^{\circ} \mathrm{C} / \mathrm{min}$. Injector temperature $250^{\circ} \mathrm{C}$; injection mode, split; split ratio 1:40; volume injected, $0.2 \mu \mathrm{L}$ of the oil. Helium was used as a carrier, using $122.2 \mathrm{kPa}(51.6 \mathrm{~cm} / \mathrm{sec})$; interface temperature $250^{\circ} \mathrm{C}$; acquisition mass range $40-400$. The second was a BP 20 (SGE, Australia) bonded fused-silica capillary column coated with polyethylene glycol $(25 \mathrm{~m} \times 0.25 \mathrm{~mm}$ i.d. x 0.25 $\mu \mathrm{m}$ film thickness); column temperature, $40^{\circ} \mathrm{C}(8$ min) to $180^{\circ} \mathrm{C}$ at $3^{\circ} \mathrm{C} / \mathrm{min}$, to $230^{\circ} \mathrm{C}$ at $20^{\circ} \mathrm{C} / \mathrm{min}$. Injector temperature $250^{\circ} \mathrm{C}$; injection mode, split; split ratio 1:40; volume injected, $0.2 \mu \mathrm{L}$ of the oil. Carrier gas was $\mathrm{He}, 92.6 \mathrm{kPa}(55.9 \mathrm{~cm} / \mathrm{sec})$; interface temperature $250^{\circ} \mathrm{C}$; acquisition mass range 40-400.

Identification and quantification: The components of the essential oil were identified by comparison of their Linear Retention Indices on the two columns, determined in relation to a homologous series of n-alkanes, with those from pure standards or reported in literature. Comparison of fragmentation patterns in the mass spectra with those stored on databases (Adams, 1995; McLafferty and Stauffer, 1991) was also performed. The quantification of the components was performed on the basis of their GC peak areas on SE-52, except those indicated in Tables 1 and 2, which were obtained on Carbowax 20M, without corrections for response factors.

Chiral Analysis: For M. pulegium essential oil, the enantiomeric ratios of menthone, isomenthone, isomenthol, menthol and pulegone were obtained by multidimensional gas chromatography, using a developmental model Mondello et al., 1998) set up with two GC ovens. The first was equipped with a column coated with SE-52 and the second with a chiral column coated with a derivatized $\beta$ cyclodextrin, a hot interface, a rotary switching valve and a system to maintain a constant flow during the transfer. With this system a heart-cut of the relevant fractions can be made and these fractions transferred from the non-chiral column to the chiral one in the following experimental conditions: precolumn, SE-52 (Mega, Legnano, 
Italy) cross-linked fused-silica capillary column coated with $5 \%$ phenyl-polymethylsiloxane $(30 \mathrm{~m}$ x $0.32 \mathrm{~mm}$ i.d. $\mathrm{x} 0.40-0.45 \mu \mathrm{m}$ film thickness); column temperature; $45^{\circ} \mathrm{C}(6 \mathrm{~min})$ to $280^{\circ} \mathrm{C}$ at $2^{\circ} \mathrm{C} / \mathrm{min} ; 280^{\circ} \mathrm{C}(15 \mathrm{~min})$; analytical columns, fused-silica capillary columns coated with 2,3-di$O$-ethyl $\quad 6-O$ - $t$-butyldimethylsilil- $\beta$-cyclodextrin (2,3-DiEtTBS- $\beta$-CDX) in PS $086 \quad(13 \%$ phenylmethyl-polysiloxane) (Mega, Legnano, Italy) $(25 \mathrm{~m} \times 0.25 \mathrm{~mm}$ i.d. $\times 0.25 \mu \mathrm{m}$ film thickness), and 2,3-di-O-acetyl 6-O-tbutyldimethylsilil- $\beta$-cyclodextrin $\quad$ (2,3-DiAcTBS-
$\beta$-CDX) in OV 1701 (14\% cyanopropyl phenylmethylpolysiloxane) Mega, Legnano, Italy) (25 m x $0.25 \mathrm{~mm}$ i.d. x $0.25 \mu \mathrm{m}$ film thickness); injection temperature, $250^{\circ} \mathrm{C}$; column temperature, $45^{\circ} \mathrm{C}(6$ min) to $90^{\circ} \mathrm{C}$ at $2^{\circ} \mathrm{C} / \mathrm{min}, 90^{\circ} \mathrm{C}(20 \mathrm{~min}) ; 90^{\circ} \mathrm{C}$ to $180^{\circ} \mathrm{C}$ at $2^{\circ} \mathrm{C} / \mathrm{min}, 180^{\circ} \mathrm{C}(10 \mathrm{~min})$; interface temperature, $200^{\circ} \mathrm{C}$; detector $\mathrm{FID}, 280^{\circ} \mathrm{C}$ (for both chromatographs). Volume injected, $1 \mu \mathrm{L}$ of an oil dilution 1:10 in n-hexane; injection mode, split; split ratio 1:15. Carrier gas was Helium, $90 \mathrm{kPa}$ (precolumn), $110 \mathrm{kPa}$ (analytical column).

Table 1 - Composition of the essential oil of M. pulegium $\mathrm{L}$

\begin{tabular}{|c|c|c|c|}
\hline \multirow[b]{2}{*}{ Constituents* } & \multirow[b]{2}{*}{$\% * *$} & \multicolumn{2}{|c|}{ LRI*** } \\
\hline & & SE-52 & CW-20M \\
\hline$\alpha$-Pinene & 0.5 & 928 & 1037 \\
\hline Camphene & $\operatorname{tr}$ & 941 & 1012 \\
\hline Sabinene & 0.1 & 965 & 1083 \\
\hline$\beta$-Pinene & 0.4 & 968 & 1083 \\
\hline Myrcene & 0.3 & 986 & 1124 \\
\hline 3-Octanone & $\operatorname{tr}$ & 978 & \\
\hline 3-Octanol & 1.5 & 994 & 1380 \\
\hline Limonene & 0.9 & 1021 & 1155 \\
\hline 1,8-Cineole & 0.1 & 1021 & 1186 \\
\hline$(1 \mathrm{R}, 4 \mathrm{~S})-(-)-$ Menthone & 3.6 & 1146 & 1461 \\
\hline$(1 \mathrm{R}, 4 \mathrm{R})-(+)$-Isomenthone & 12.9 & 1159 & 1420 \\
\hline neo-Menthol & 0.3 & 1161 & 1599 \\
\hline Isopulegone & 1.4 & 1167 & 1533 \\
\hline$(1 \mathrm{R}, 3 \mathrm{R}, 4 \mathrm{~S})-(-)-$ Menthol & 0.6 & 1178 & 1599 \\
\hline$(1 \mathrm{R}, 3 \mathrm{~S}, 4 \mathrm{R})-(+)-$ Isomenthol & 0.1 & & 1686 \\
\hline neo-Isomenthol & 0.8 & 1180 & 1622 \\
\hline$\alpha$-Terpineol & 0.1 & 1189 & 1652 \\
\hline (1R)-(+)-Pulegone & 73.4 & 1241 & 1637 \\
\hline Piperitone & 0.1 & 1247 & 1697 \\
\hline Piperitenone & 0.9 & 1329 & 1851 \\
\hline (E)-Caryophyllene & 0.1 & 1410 & 1563 \\
\hline$\alpha$-Humulene & 0.9 & 1445 & 1642 \\
\hline Caryophyllene oxide & 0.3 & 1572 & \\
\hline Monoterpene hydrocarbons & 2.2 & & \\
\hline Oxygen-containing monoterpenes & 94.3 & & \\
\hline Sesquiterpene hydrocarbons & 1.0 & & \\
\hline Oxygen-containing sesquiterpenes & 0.3 & & \\
\hline Others & 1.5 & & \\
\hline Total identified (\%) & 99.3 & & \\
\hline
\end{tabular}

\section{RESULTS AND DISCUSSION}

The results obtained in the analysis of the essential oils of M. pulegium and M. rotundifolia are shown in Tables 1 and 2, respectively. Twenty two different components were identified in the essential oil of $M$. pulegium, meaning $99.3 \%$ of the total sample (Table 1). Oxygenated monoterpenes $(94.3 \%)$ were found to be the major group of 
constituents, the main one being pulegone (73.4\%) followed by isomenthone (12.9\%). The enantiomeric ratio of the five main components (menthone, isomenthone, isomenthol, menthol and pulegone) was established for M. pulegium oil by subsequent transfers during different analysis using two chiral stationary phases. Under the experimental conditions, menthol was best resolved on 2,3-DiAcTBS- $\beta$-CDX, while menthone, pulegone, isomenthol and isomenthone were best resolved on 2,3-DiEtTBS- $\beta$-CDX. To improve the separation on the second chiral phase (2,3-DiEtTBS- $\beta$-CDX) menthone and pulegone were analysed in one chromatographic run and isomenthol and isomenthone in a second one.

Table 2 - Composition of the essential oil of M. rotundifolia (L.) Huds.

\begin{tabular}{|c|c|c|c|}
\hline \multirow[b]{2}{*}{ Constituents* } & \multirow[b]{2}{*}{$\% * *$} & \multicolumn{2}{|c|}{$\mathrm{LRI}^{* * *}$} \\
\hline & & SE-52 & CW-20M \\
\hline$\alpha$-Pinene & 0.5 & 927 & 1000 \\
\hline Sabinene & 0.7 & 962 & 1076 \\
\hline$\beta$-Pinene & 0.7 & 970 & 1065 \\
\hline 1-Octen-3-ol & 0.9 & 977 & 1406 \\
\hline Myrcene & 0.8 & 989 & 1120 \\
\hline$\alpha$-Terpinene & 0.1 & & 1138 \\
\hline p-Cymene & 0.7 & 1024 & 1208 \\
\hline Limonene & 0.8 & 1024 & 1155 \\
\hline$\beta$-Phellandrene & $\operatorname{tr}$ & & 1163 \\
\hline 1,8-Cineole & 0.1 & & 1168 \\
\hline (Z)-b-Ocimene & 0.8 & 1040 & 1182 \\
\hline (E)-b-Ocimene & 0.1 & 1048 & 1200 \\
\hline (Z)-Sabinene hydrate & 2.0 & 1068 & \\
\hline Octen-3-yl acetate & 0.2 & 1115 & 1323 \\
\hline 4-Terpineol & 1.5 & 1177 & 1551 \\
\hline$\alpha$-Terpineol & 0.2 & & 1655 \\
\hline Piperitenone oxide & 80.8 & 1386 & 1940 \\
\hline$\beta$-Longipinene & 0.2 & 1410 & \\
\hline (E)-Caryophyllene & 0.4 & 1415 & 1516 \\
\hline$\beta$-Farnesene & 0.8 & 1457 & 1583 \\
\hline Germacrene D & 0.6 & 1479 & 1613 \\
\hline (E)-Nerolidol & 0.1 & 1572 & \\
\hline Globulol & 0.4 & 1590 & \\
\hline Monoterpene hydrocarbons & 5.3 & & \\
\hline $\begin{array}{l}\text { Oxygen-containing } \\
\text { monoterpenes }\end{array}$ & 84.6 & & \\
\hline Sesquiterpene hydrocarbons & 2.0 & & \\
\hline $\begin{array}{l}\text { Oxygen-containing } \\
\text { sesquiterpenes }\end{array}$ & 0.5 & & \\
\hline Others & 1.1 & & \\
\hline Total identified (\%) & 93.5 & & \\
\hline
\end{tabular}

* Components listed according to their elution order on SE-52.

**Percentages were obtained on SE-52, except for $\alpha$-terpinene, limonene, ß-phellandrene, 1,8-cineole and $\alpha$-terpineol, which were obtained on Carbowax 20M.

*** LRI: Linear Retention Indices in relation to n-alkanes.

Enantiomerically pure $(1 R, 4 S)-(-)$-menthone, $(1 R, 4 R)-(+)$-isomenthone, $\quad(1 R, 3 S, 4 R)-(+)-$ isomenthol, $(1 R, 3 R, 4 S)-(-)-$ menthol and $(1 R)-(+)-$ pulegone were detected in the essential oil of $M$. pulegium (Table 1). This result agrees with that biosynthetically expected, since (-)-menthone and $(+)$-isomenthone are the precursors of (-)-menthol and $(+)$-isomenthol, respectively. All five chiral monoterpenoids occurred as pure $(1 R)$ configurated enantiomers, resulting in an useful tool for the identification and genuineness of this oil, particularly in the case of the optically pure 
$(+)$-pulegone, where previous results (Ravid, 1998) indicated lower values for M. pulegium oils. In conclusion, the basic composition of the oil of M. pulegium from Uruguay was similar to that reported previously (Bigo and Moyna, 1985), although higher percentages of neo-menthol and pulegone and lower ones for isomenthone were found in the sample investigated. As (+)-pulegone is the precursor of (-)-menthone and (+)isomenthone in the biosynthesis of monoterpenes in the genus Mentha, the results could indicate possible variations in the biosynthetic behaviour for the population studied. Furthermore, the role of $(+)$-pulegone as a chiral starting material for enantioselective synthesis of natural products, supports the potential application of the essential oil from the selected population of Mentha pulegium from Uruguay as a source of enantiomerically pure $(+)$-pulegone.

The analysis of the oil of $M$. rotundifolia allowed the identification of 23 components, which corresponded to a $93.5 \%$ of the total (Table 2). The major constituent was piperitenone oxide $(80.8 \%)$, an oxigenated monoterpene which has been reported to characterise the volatile oil of some chemotypes of Mentha sp., such as M. spicata (Pino et al., 1998), M. longifolia (Venskutonis, 1996), M. x villosa (Abreu Matos et al., 1999) and M. rotundifolia (Nagell and Hefendehl, 1974). Previous studies on the essential oil of $M$. rotundifolia revealed the existence of chemotypes with different major components, as for example piperitone oxide (Kokkini and Papageorgiou, 1988; Hendriks and Van Os, 1976), menthyl acetate (Kokkini and Papageorgiou, 1988), dihydrocarvone (Hendriks and Van Os, 1976) and also piperitenone oxide (Nagell and Hefendehl, 1974), indicating that the Uruguayan population could be a representant of the chemotype reported for Nagell et al. (Nagell and Hefendehl, 1974).

\section{ACKNOWLEDGEMENTS}

The authors are grateful to the European Commission and the Uruguayan Government (Project COTEPA, URY/B7-3011/95/231, through the Foundation Bosch i Gimpera of the University of Barcelona), the Programa Iberoamericano de Ciencia y Tecnología para el Desarrollo (CYTED, Project IV-6), the Instituto Nacional de Investigaciones Agropecuarias (INIA, grant $\mathrm{n}^{\mathrm{o}}$
098) and the University of Barcelona (International relationship actions), that gave financial support.

\section{RESUMO}

Óleos essenciais obtidos por hidrodestilação das folhas de Mentha pulegium L. e Mentha rotundifolia (L.) Huds. do Uruguay foram analisados por GC-FID e GC-MS. O grupo de monoterpenes oxigenados foi o mais importante em ambos os óleos, sendo que a pulegona, isomenthona e menthona foram os constituintes maioritarios no óleo de Mentha pulegium, no entanto, o ôxido de piperitenona e (Z)-hidrato de sabineno foram os maioritarios na Mentha rotundifolia. (-)-Mentone, (+)-isomentone, (+)isomenthol, (-)-menthol e (+)-pulegone enantioméricamente puras foram detectadas por cromatografía gasosa multidimensional no caso do óleo de Mentha pulegium.

\section{REFERENCES}

Abreu Matos, F. J.; Lacerda Machado, M. I.; Craveiro, A. A.; Alencar, J. W.; Barbosa, J. M. E.; Leitao da Cunha, V. and Hiruma, C. A. (1999), Essential oil of Mentha x villosa from Northeastrn Brazil. J. Essent. Oil Res., 11, 41-44.

Adams, R. P. (1995), Identification of Essential Oils by Gas Chromatography/Mass Spectroscopy. Allured Publ. Corp., Carol Stream, IL.

Bigo de Grosso, M. and Moyna, P. (1985), Composición química de las esencias de Mentha del Uruguay. An. Real Acad. Farm., 51333-338.

Brophy, J. J.; Goldsack, R. J.; Lawrence, B. M. and Forster, P. I. (1996), Essential oil of Mentha diemenica (Lamiaceae). J. Essent. Oil Res., 8, 179-181.

Hefendehl, F. (1970), Beiträge zur biogenese ätherischer Öle von Mentha pulegium L. Phytochemistry, 9, 1985-1995.

Hendriks, H. and Van Os, F. H. L. (1976), Essential oil of two chemotypes of Mentha suaveolens during ontogenesis. Phytochemistry, 15, 1127-1130.

Hendriks, H.; Van Os, F. H. L. and Feenstra, W. J. (1976), Crossing experiments between some chemotypes of Mentha longifolia and Mentha suaveolens. Planta Med., 30154-162.

Kokkini, S. and Papageorgiou, V. (1988), Constituents of essential oils from Mentha rotundifolia growing wild in Greece. Planta Med., 5,4166-167. 
Kokkini, S. and Vokou, D. (1989), Mentha spicata (Lamiaceae) chemotypes growing wild in Greece. Econ. Bot., 43192-202.

Lawrence, B. M. (1978), A Study of the Monoterpene Interrelations in the Genus Mentha with Special Reference to the Origin of Pulegone and Menthofuran. PhD Thesis, Rijksuniversiteit, Groningen.

Lawrence, B. M. (1998), Progress in essential oils. Perfumer-and-Flavorist; 23, 63-68.

Maffei, M. (1988), A chemotype of Mentha longifolia (L.) Hudson particularly rich in piperitenone oxide. Flav. Fragr. J., 3, 23-26.

McLafferty, F. W. and Stauffer, D. B. (1991), The Wiley/NBS Registry of Mass Spectral Data, $5^{\text {th }} \mathrm{ed}$. New York: Wiley and Sons.

Misra, L. N.; Tyagi, B. R. and Thakur, R. S. (1989), Chemotypic variation in Indian spearmint. Planta Med, 55, 575-576.

Mondello, L., Catalfamo, M.; Dugo, P. and Dugo, G. (1998), Multidimensional tandem capillary gas chromatography system for the analysis of real complex samples. Part I. Development of a fully automated tandem gas chromatography system. J. Chromatogr. Sci., 36, 201-209.

Nagell, A. and Hefendehl, F. W. (1974), Zusammensetzung des Ätherischen Öles vom Mentha rotundifolia. Planta Med., 26, 1-8.
Newall, C. A.; Anderson, L. A. and Phillipson, J. D. (1996), Herbal Medicines. A guide for Health-care Proffessionals. London: The Pharmaceutical Press.

Pino, J. A.; Rosado, A. and Fuentes, V. (1996), Chemical composition of the essential oil of Mentha pulegium L. from Cuba. J. Essent. Oil Res., 8, 295-296.

Pino, J. A.; Rosado, A. and Sánchez, E. (1998), Essential oil of Mentha spicata L. from Cuba. J. Essent. Oil Res., 10, 657-659.

Ravid, U. (1998), Enantiomeric distribution of oxygenated monoterpenes in some Mentha essentiaol oils. Perf. and Flav., 2325-30.

Umemoto, K. (1998), Two new stereoisomers of 1,2-epoxymenthyl acetate from self-pollinated plant oils of Mentha rotundifolia. Nat. Prod. Lett., 11, 161165.

Venskutonis, P. R. (1996), A chemotype of Mentha longifolia L. from Lithuania rich in piperitenone oxide. J. Essent. Oil Res., 8, 91-95.

Received: May 07, 2001; Revised: September 10, 2001; Accepted: January 18, 2002. 